\title{
Development of a Grid-Based Rural Electrification Design: A Case Study of Ishashi and Ilogbo Communities in Lagos State, South Western Nigeria
}

\author{
Oyejide, S.A. ${ }^{1}$, Adejumobi, I.A. ${ }^{1}$, Wara, S.T. ${ }^{1}$, Ajisegiri, E.S.A. ${ }^{2}$ \\ ${ }^{1}$ (Department of Electrical and Electronics Engineering, Federal University of Agriculture, Abeokuta, Nigeria) \\ ${ }^{2}$ (Department of Agricultural Engineering, Federal University of Agriculture, Abeokuta, Nigeria)
}

\begin{abstract}
This work presents the development of a grid-based rural electrification design using Ishashi and Ilogbocommunities in Lagos State, South Western Nigeria as case studies. Grid-based and off-grid based methods are two commonly employed rural electrification technologies but in this work grid-based method was employed because of its simplicity, flexibility, sustainability and cost effectiveness. Load audits of Ishashi and Ilogbo were carried out to determine their energy demands. To cater for future expansion of both communities, a fifteen year load growth was calculated using the derived load growth equations. Design equations were used to determine ratings and quantities of substation components required for the electrification. The inter-township connection and township distribution network lengths for both Ishashi and Ilogbo were also determined. The proposed electrical model designs for the two communities were implemented using AutoCAD 2012 Version Software. The energy demand of both Ishashi and Ilogbo were respectively $0.91 \mathrm{MW}$ and $0.61 \mathrm{MW}$ and their estimated fifteen years load growth were $3.26 \mathrm{MW}$ and $2.20 \mathrm{MW}$ respectively. The average load demand of both Ishashi and Ilogbo were respectively $1.31 \mathrm{MW}$ and $0.88 \mathrm{MW}$ using a load factor of 0.4. With the use of average load demand, the inter-township connection and township distribution network lengths of Ishashi $(2.65 \mathrm{~km}$ and $8.72 \mathrm{~km}$ respectively) and Ilogbo $(1.13 \mathrm{~km}$ and $7.44 \mathrm{~km}$ respectively), the required quantities of the major substation components required for implementation of developed electrical model designs were obtained.
\end{abstract}

Keywords: Electrification technology, grid-based method, rural electrification, energy demand, Nigeria

\section{Introduction}

Rural electrification is one of the key challenges facing rural communities in most developing countries of the world including Nigeria. However, since electricity is an essential component in the development of any community, there is the need to develop a means of increasing access to electrical energy services for rural communities in Nigeria if the set target of the Millennium Development Goals' declarationis to be achievedas a whole.

Rural communities in most developing countrieshave limited access to all forms of life enriching services such as good health care delivery, pipe borne water, good communication and road networks [1]. Access to electrical energy is not an exception. For instance, in Nigeria electricity utility is far from within the reach of the majority of the rural dwellers whose population is about six-five per cent $(65 \%)$ of the total populace $[2,3,4]$. With demand for electrical energy far from matching its supply, the rural dwellers face major challenges of very inadequate and epileptic power supply made worse by poor quality of services.

Appropriate technology through which electricity can be optimally supplied to rural communities has been identified as one of the major solutions to address the problems of rural electrification [5]. In some cases, grid extension may be feasible and cost effective particularly for dense and concentrated rural populations. In other situations where there are dispersed populations particularly remote locations, grid extension may be physically and economically inefficient. More so, in cases where grid electricity is available, supply is often epileptic and of poor quality. Where alternatives to the grid exist, such as solar home lighting systems available at subsidized rates, the technology itself is unsustainable unless accompanied by effective follow-up servicing and maintenance support. Also, provision of electricity, particularly through off-grid renewable energy technologies, does little to significantly raise standard of living unless it also enables income generation [5]. These challenges altogether are some of the issues that needed to be urgently resolved before effective rural electrification system can be put in place.

In this work, our goal is to develop a grid-based rural electrification design usingIshashi and Ilogbo, two rural communities in Lagos State, South Western Nigeria as case studies. These two communities despite being located within a state regarded as first and most viable commercial centre in Nigeria with added advantage of having an existing functional grid (33 kV feeder) passing through them which could easily be extended, they still remained unelectrified. 


\section{Rural Electrification}

Rural electrification is a concept very difficult to be accorded a specific definition as it is used differently in different countries of the world, however, with the same convergent view point. As reported in Zomers [6], Munasinghe (1990) noted that most often the term rural electrification refers to connections to a central grid. Vogel (1993) reported that according to International Agencies such as the World Bank, the concept of rural electrification does not only refer strictly to rural areas as defined in the country statistics but may also include small to medium-sized towns which are service centres for the surrounding rural areas within a given region. Yaron et al. (1994) stated that rural electrification is the process of bringing electricity to rural communities. Mason (1990) reported that most of the rural electrification projects in the past referred to communities of between 500 and 2000 people.

One of the consequences of the differences in interpretation of the concept of rural electrification is that comparison between rural electrification projects in different countries is extremely difficult if not impossible.However, the convergent point of all the views highlighted above is that rural electrification is the process of electrifying rural or remote community. In Nigeria, a rural community officially is defined as one with a population of less than 20,000 with an assumed average household of 10 [2].

Rural electrificationoften impacts greatly on the rural lives. Apart from improving the living standards of the dwellers, it is a catalyst for the overall rural development. It assists in reducing rural-urban migration which in turn helps alleviates urban congestion and its associated social vices such as poverty and crime. It also helps to promote political stability and increase social virtues such as an improved health care delivery, creation of employment, upliftment of the education system and the social cohesion and development in rural communities.

\subsection{Rural Electrification Technologies}

The technologies employed for rural electrification in different countries differ considerably depending of local circumstances and the degree of saturation of the electricity supply grid. Two basic technologies usually employed for electrification of rural communities are the grid-based and offgrid-based technologies.

\subsubsection{Grid-based Technology}

The grid-based technology simply involves the extension of the existing functional electricity grid to the area or community to be electrified. It is the most straight-forward method for electrification of the majority of rural communities. It is very flexible, sustainable and cost effective. For a rural community located at a far remote end and difficult terrain such mountainous or hilly region, however, this technology may be economically challenging.

\subsubsection{Offgrid-based Technology}

The offgrid-based technology usually involves the use of isolated generators or renewable energy techniques such as biomass gasification, small hydropower schemes, wind hybrid and solar photovoltaic to electrify a given area or community. The use of offgrid-based technology, particularly renewable energy techniques in rural electrification may be advantageous in terms of environmental impacts; however, the design of new supply system makes this technology more challenging.

\section{Design Considerations}

An effective design ensures the supply of service under adequate technical conditions and at minimum cost. In order to develop an efficient grid-based rural electrification design for Ishashi and Ilogbo communities, the following design procedures were considered in this work.

\subsection{Survey and Analysis}

This involves visitation to Ishashi and Ilogbo communities to observe the communities conditions, check their topographies, determine the quantity and characteristics of consumers.

\subsection{Load Estimation}

This involves the estimation of the consumers' loads that is load audit of the two communities.

\subsection{System Configuration}

This involves the choice of the supply system $(33 \mathrm{kV}$ or $11 \mathrm{kV})$ to be employed for electrifying the two communities and its components such as route design, features of primary lines, and location of transformer substations. 


\subsection{Development of Electrical Model Design}

This involves implementation of the design considerations to obtain the electrical design layout of both Ishashi and Ilogbo communities.

\section{4. Design Equations}

In this section of the work, useful equations that are crucial to development of the electrical model design of Ishashi and Ilogbo communities are presented. Based on the estimated load demand of each household within a village, the overall energy requirement, $P_{\text {erv }}$ in kilowatt $(\mathrm{kW})$ of each of the villages within the two communities will be calculated using equation (1):

$\mathrm{P}_{\text {erv }}=\mathrm{P}_{\mathrm{h}} \mathrm{n}$

Where $\mathrm{P}_{\mathrm{h}}=$ Energy requirement of each household in kilowatt $(\mathrm{kW})$ $\mathrm{n}=$ Number of households (including other energy users) in a given village

With $30 \%$ of the total estimated energy requirement of the individual community allowed to cater for future expansion [7], the overall energy requirement $P_{e r}$ in kilowatts $(\mathrm{kW})$ of $\mathrm{N}$ number of villages to be served by a given substation will be calculated by equation (2):

$\mathrm{P}_{\mathrm{er}}=1.3 \sum_{\mathrm{i}}^{\mathrm{N}} \mathrm{P}_{\text {ervi }}$

Since the allowed $30 \%$ increase of the total estimated load demand of each community will not be constant for the periods for which load growth is expected, then, equation (2) is modified into equations (3), (4) and (5) respectively to allow for $15 \%$ load increase for the first growth period, $10 \%$ load increase for the second growth period and 5\% load increase for the third growth period). The equations (3), (4) and (5) are termed load growth equations:

$$
\begin{aligned}
& \mathrm{P}_{\text {er } 1}=1.15 \sum_{\mathrm{i}}^{\mathrm{N}} \mathrm{P}_{\text {ervi }} \\
& \mathrm{P}_{\text {er } 2}=1.10 \sum_{\mathrm{i}}^{\mathrm{N}} \mathrm{P}_{\text {ervi }} \\
& \mathrm{P}_{\text {er } 3}=1.05 \sum_{\mathrm{i}}^{\mathrm{N}} \mathrm{P}_{\text {ervi }}(5)
\end{aligned}
$$

Where $\mathrm{P}_{\mathrm{er} 1}=$ Total energy demand for the first growth period in $\mathrm{kW}$

$\mathrm{P}_{\mathrm{er} 2}=$ Total energy demand for the second growth period in $\mathrm{kW}$

$\mathrm{P}_{\mathrm{er} 3}=$ Total energy demand for the final growth period in $\mathrm{kW}$

For the sizing of the distribution transformer to serve $\mathrm{N}$ number of villages in a community, equation (6) will be used:

$S=\frac{P_{\text {ergp }}}{\cos \emptyset}$

Where $\mathrm{S}=\mathrm{kVA}$ rating equivalent to energy consumption of $\mathrm{N}$ number villages with $30 \%$

allowance connected to a substation to determine the size of the distribution

transformer.

$\mathrm{P}_{\text {ergp }}=$ Total load demand at the end of the assumed growth period with due

consideration of the load factor.

$\cos \emptyset=$ Power factor (for purpose of this work, $\cos \emptyset$ will be taken as 0.8 )

Load factor is the ratio of average demand to the maximum demand during a certain period of time which could be a day, month or year [8]. It is usually less than unity and characteristically very low for rural community. It is expressed by equation (7) [8]:

$$
\begin{aligned}
& \text { Load factor }=\frac{D_{\text {ave }}}{D_{\max }}(7) \\
& \text { Where } D_{\text {ave }}=\text { Average demand in } \mathrm{kW} \\
& D_{\max }=\text { Maximum demand in } \mathrm{kW}
\end{aligned}
$$


The rated current $I_{i}$ in amperes of each distribution transformer to serve a village within a community will be estimated by the equation (8):

$\mathrm{I}_{\mathrm{i}}=\frac{\mathrm{S}}{\sqrt{3} \mathrm{~V}_{\mathrm{L}-\mathrm{L}}}$

Where $\mathrm{V}_{\mathrm{L}-\mathrm{L}}=$ Line-to-line voltage $(\mathrm{kV})$ for three phase supply system $\mathrm{i}=$ Specific village in a community

\subsection{Design Considerations for Substation Components}

The components of interest in this section include distribution transformer, feeder pillar, protective devices, conductors and cables, poles, insulators and stay/guy wires.

\subsubsection{Distribution transformer}

It is one of the essential items of any substation. In power generation, transformers generally allow the relatively low voltages from generators to be raised to a very high level for efficient power transmission and at the user end of the system; they reduce the voltage to values most suitable for utilization [9]. For this work, equation (6) will be used to determine the size and number of required substation transformers.

\subsubsection{Feeder pillar}

Itconsists of set of conductors (typically copper conductors) which connect the substation to the areas to be fed with electricity supply. No tapping is done directly from feeder pillar to the consumers' premises. For this work, the size of the feeder pillar will be determined using equation (8).

\subsubsection{Conductors and Cables}

Overhead conductors and cables are another set of essential components for any substation. In this work, the sizes of conductors and cables will be determined primarily by the rated primarily and secondary currents of the distribution transformers. In the final selection of the conductor or cable, the following factors will be considered: the conductor or cable must be able to carry the maximum current liable to flow in the circuit without undue heating and the voltage drop caused by the resistance of the conductor or cable must not be excessive. The total length of run of the overhead conductor will be calculated using equation (9) given by:

Total length of conductor $=\quad \mathrm{L} \times 3($ or 4 or 5$)$

Where $\mathrm{L}=$ Length of conductor per phase in metres

The choice of constant 3 or 4 or 5 in equation (9) arises from whether we are considering high tension lines $(11$ or $33 \mathrm{kV})$ which usually consist of three sets of conductors (3-phase) or low tension lines $(0.415 \mathrm{kV})$ which usually consist of four sets of conductors (3-phase and neutral) or five sets of conductors with street lighting considered. However, with sagging or wastage factor (S.F) considered, equation (9) becomes modified as equation (10):

Total length of conductor $=\mathrm{L} \times 3($ or 4 or 5$) \times \mathrm{S} . \mathrm{F}$

\subsubsection{Pole}

Poles are supporting structures which carry the overhead conductor. They are of different types. They could be wooden, concrete or steel reinforce types. The application of supporting structures is presented in Table 1.

Table 1:Application of supporting structure [10]

\begin{tabular}{|l|l|}
\hline Supporting structure & Application \\
\hline Concrete poles & Generally applied \\
\hline $\begin{array}{l}\text { Wooden poles (including } \\
\text { Bamboo poles) }\end{array}$ & Applied to areas where access of heavy machines is difficult \\
\hline Steel poles & Applied to areas where access of heavy machines is difficult \\
\hline
\end{tabular}

In this work, the number of selected pole type to carry the overhead conductor will be determined from equation (11) given by:

Number of pole $=\frac{\mathrm{L}}{\mathrm{S}_{\mathrm{opt}}}(11)$ 
Where $\mathrm{S}_{\mathrm{opt}}=$ Optimum span in metres

The span between poles, height of poles and pole setting depth will be specified using applicable standards. The length of the span between distribution line supports (poles) will be specified using the standard recommended by JICA [10]:

- Recommended Span is $50 \mathrm{~m}$.

- Maximum $80 \mathrm{~m}$, for areas outside settlements, areas for rice fields, and open spaces.

- Maximum $50 \mathrm{~m}$, for areas within the population settlement.

The minimum clearances of conductors above ground, typical spacing of overhead conductor and the typical pole heights are presented in Tables 2, 3 and 4 respectively.

Table 2: Conductor clearance to ground [8]

\begin{tabular}{|c|c|c|c|c|c|c|c|}
\hline \multirow{2}{*}{ Clearance to ground in metres } & \multicolumn{9}{|c|}{ Line voltage in kV } \\
\cline { 2 - 9 } & $\mathbf{0 . 4}$ & $\mathbf{1 1}$ & $\mathbf{3 3}$ & $\mathbf{6 6}$ & $\mathbf{1 3 2}$ & $\mathbf{2 2 0}$ & $\mathbf{4 0 0}$ \\
\hline Across Street & 5.8 & 5.8 & 6.1 & 6.1 & 6.1 & 7.0 & 8.4 \\
\hline Along Street & 5.5 & 5.5 & 5.8 & 6.1 & 6.1 & 7.0 & 8.4 \\
\hline Other Areas & 4.6 & 4.6 & 5.2 & 5.5 & 6.1 & 7.0 & 8.4 \\
\hline
\end{tabular}

Table 3: Typical spacing value of overhead conductor [8]

\begin{tabular}{|c|c|c|c|c|c|c|c|c|}
\hline Line voltage in kV & 0.4 & 11 & 33 & 66 & 132 & 220 & 400 & 765 \\
\hline Spacing in metres & 0.2 & 1.2 & 2.0 & 2.5 & 3.5 & 6.0 & 11.5 & 14 \\
\hline
\end{tabular}

Table 4: Recommended height of supporting structures [7]

\begin{tabular}{|c|c|}
\hline Pole type & Recommended support length \\
\hline High tension $(33 \mathrm{kV})$ & $33 \mathrm{ft}(10.06 \mathrm{~m})$ \\
\hline Low tension $(0.415 \mathrm{kV})$ & $28 \mathrm{ft}(8.5 \mathrm{~m})$ \\
\hline
\end{tabular}

The pole setting depth in metres will be calculated from equation (12) given by JICA [10]:

Pole setting depth $=\mathrm{L}_{\mathrm{P}} \times \frac{1}{6}(12)$

Where $\mathrm{L}_{\mathrm{P}}=$ Pole length in metres

\subsubsection{Disc Insulator}

Disc insulator is also an essential component of any substation which is usually carried by the section or terminal poles. It helps to give the necessary tension to the overhead lines, specifically, the high tension lines. Apart from the fact that the disc insulator must be of rating consistent with the voltage level of the incoming high tension line, its total number employed for any electrification work is usually determined by the number of section poles, terminal poles and Tee off points for 11 or $33 \mathrm{kV}$ lines

\subsubsection{Section Pole}

A section pole is an ' $\mathrm{H}$ ' pole inserted into the high tension (11 or $33 \mathrm{kV}$ line) where additional strengthen is required, stayed both ways in the direction of the line route and with the conductors tensioned by disc insulators on each side of pole. Therefore, for an $11 \mathrm{kV}$ line, three (3)disc insulators are needed on one side of the pole arranged one per phase whereas $33 \mathrm{kV}$ line requires onlynine (9) disc insulators on one side of the pole only arranged three per phase. Hence, for one (1) section pole, an $11 \mathrm{kV}$ line requires a total of six (6) disc insulators whereas $33 \mathrm{kV}$ line requires eighteen (18) disc insulators are required.

\subsubsection{Terminal Pole}

A terminal pole is an ' $\mathrm{H}$ ' pole with the conductors erected on one side only and made tensioned by disc insulators. From this definition, an $11 \mathrm{kV}$ linerequires only three (3) disc insulators at the terminal pole/line arranged one per phase where $33 \mathrm{kV}$ line requires only nine (9) disc insulators at the terminal poles/linearranged three per phase.

\subsubsection{Pin Insulator and Shackle Insulators}

Pin and shackle insulators are respectively used to support high tension and low tension conductors. For any design work, the rating of pin insulator must be consistent with voltage level of the in-coming high tension line (11 or $33 \mathrm{kV}$ line) while the shackle insulator must be of rating consistent with the low tension line 
(415 V rating). Also, the number of pin and shackle insulators is dependent on the number of high and low tension poles employed for a given design work.

One other important factor that must be considered in determining the total number of disc and pin insulators for a given design work is the tee-off point. At this point, the direction of high tension line usually changed. Depending on whether it is single-channelled or double-channelled, three additional pin insulators are needed if it is single-channelled or three additional pin insulators and disc insulators are needed if it is doublechannelled.

\subsubsection{Cross Arms}

The cross arms are the supports which carry the components such as pin and disc insulators and all other accessories associated with them. The number of cross arms is usually determined by the number of high tension poles with due consideration of the ones that would carry other accessories at the transformer substation and section poles.

\subsubsection{Guy and Stays}

These are usually installed to balance the pole. The theoretical angle between the pole and stay should be $45^{\circ}[8]$ but in general practice it is not always possible to obtain this and so stay design is generally based on a minimum angle of $30^{\circ}$ between the stay and pole $[8]$.

\subsubsection{Protective Devices}

Protective devices are usually installed to protect the substation components from damage due to faults or surges. The most common protective devices found in transformer substation are J \& P fuses and lightning arresters. Another form of protective devices in the transformer substation is gang isolator which is normally being used in breaking the substation from in-coming high tension for the purpose of maintenance. Insulators of different types are also being used for protection of substation components such as overhead conductor apart from supporting them mechanical.The choice of protective devices is usually dependent on the level of voltage used for the design.

\section{Results and Discussion}

The survey carried out on Ishashi and Ilogbo communities revealed that there were respectively over 150 and 100 buildings of different plans and patterns within the two communities. The survey exercise also revealed that the individual community population was well below 20, $000(16,800$ for Ishashi and 12, 000 for Ilogbo) which is within the range reported in Adejumobi and Adebisi [3] for official definition of rural community in Nigeria and also in conformity with Chaurey et al. [5] where they reported that a rural community could be of dense and concentrated populations.

In order to estimate the load demand (energy requirement) of both Ishashi and Ilogbo communities, lighting and power loads were given priority for all the building types. Tables 5 and 6 show respectively the estimated total load demands of Ishashi and Ilogbo using equation (1).

Table 5: Total load demand of Ishashi Community

\begin{tabular}{|c|c|c|c|c|}
\hline S/N & Category of buildings & Number of buildings & $\begin{array}{c}\text { Estimated consumption per } \\
\text { category of buildings (kW) }\end{array}$ & $\begin{array}{c}\text { Initial total load demand per } \\
\text { category of buildings (kW) }\end{array}$ \\
\hline 1 & Bungalow & 112 & 5.50 & 616.00 \\
\hline 2 & Storey building & 19 & 9.63 & 182.97 \\
\hline 3 & Shop & 11 & 1.80 & 19.80 \\
\hline 4 & Nursery/Primary school & 5 & 8.25 & 41.25 \\
\hline 5 & Secondary school & 0 & 8.25 & 0.00 \\
\hline 6 & Church & 4 & 5.53 & 5.80 \\
\hline 7 & Mosque & 2 & 2.90 & 19.78 \\
\hline 8 & Mini industry & 2 & 9.89 & 907.72 \\
\hline & Total & & & \\
\hline
\end{tabular}

Table 6: Total load demand of Ilogbo Community

\begin{tabular}{|c|c|c|c|c|}
\hline S/N & Category of buildings & Number of buildings & $\begin{array}{c}\text { Estimated consumption per } \\
\text { category of buildings (kW) }\end{array}$ & $\begin{array}{c}\text { Initial total load demand per } \\
\text { category of buildings (kW) }\end{array}$ \\
\hline 1 & Bungalow & 74 & 5.50 & 407.00 \\
\hline 2 & Storey building & 14 & 9.63 & 134.82 \\
\hline 3 & Shop & 8 & 1.80 & 14.40 \\
\hline 4 & Nursery/Primary school & 2 & 8.25 & 16.50 \\
\hline 5 & Secondary school & 0 & 8.25 & 0.00 \\
\hline 6 & Church & 3 & 5.53 & 16.59 \\
\hline 7 & Mosque & 1 & 2.90 & 2.90 \\
\hline 8 & Mini industry & 2 & 9.89 & 19.78 \\
\hline & Total & & \\
\end{tabular}


In order to cater for future expansion of both Ishashi and Ilogbo communities, a fifteen-year load growth had been considered in this work. For the period between 1-5 years, a load increase at the rate of $15 \%$ was assumed. Next, the period between 6-10 years was assumed to experience a load increase at the rates of $10 \%$ and finally, the period between 11-15 years was assumed to experience a load increase at the rate of $5 \%$. Hence, with these assumptions, equations (3), (4) and (5) were used to estimate total load demand of Ishashi and Ilogbo for the period of fifteen (15) years. The estimated 15 years load growth of the two communities is presented in Tables 7 and 8 respectively.

Table 7: 15 years load growth of Ishashi community

\begin{tabular}{|c|c|c|}
\hline Period (yrs) & $\begin{array}{l}\text { Percent }(\%) \text { increase of the load } \\
\text { demand }\end{array}$ & Expected load demand (kW) \\
\hline 1 & - & 907.72 \\
\hline 2 & \multirow{4}{*}{$15 \%$} & $1,043.88$ \\
\hline 3 & & $1,200.46$ \\
\hline 4 & & $1,380.53$ \\
\hline 5 & & $1,587.61$ \\
\hline 6 & \multirow{5}{*}{$10 \%$} & $1,746.37$ \\
\hline 7 & & $1,921.01$ \\
\hline 8 & & $2,113.11$ \\
\hline 9 & & $2,324.42$ \\
\hline 10 & & $2,556.86$ \\
\hline 11 & \multirow{5}{*}{$5 \%$} & $2,684.70$ \\
\hline 12 & & $2,818.94$ \\
\hline 13 & & $2,959.89$ \\
\hline 14 & & $3,107.88$ \\
\hline 15 & & $3,263.27$ \\
\hline
\end{tabular}

Table 8: 15 years load growth of Ilogbo community

\begin{tabular}{|c|c|c|}
\hline Period (yrs) & $\begin{array}{l}\text { Percent }(\%) \text { increase of the load } \\
\text { demand }\end{array}$ & Expected load demand (kW) \\
\hline 1 & - & 611.99 \\
\hline 2 & \multirow{4}{*}{$15 \%$} & 703.79 \\
\hline 3 & & 809.36 \\
\hline 4 & & 930.76 \\
\hline 5 & & $1,070.37$ \\
\hline 6 & \multirow{5}{*}{$10 \%$} & $1,177.41$ \\
\hline 7 & & $1,295.15$ \\
\hline 8 & & $1,424.67$ \\
\hline 9 & & $1,567.14$ \\
\hline 10 & & $1,723.85$ \\
\hline 11 & \multirow{5}{*}{$5 \%$} & $1,810.04$ \\
\hline 12 & & $1,900.54$ \\
\hline 13 & & $1,995.57$ \\
\hline 14 & & $2,095.35$ \\
\hline 15 & & $2,200.12$ \\
\hline
\end{tabular}

Since rural community is usually characterised by low load factor of $0.2-0.4[1,11,12]$, the use of load factor of 0.4 , the upper limit considered in this work, equation (7) and fifteenth $\left(15^{\text {th }}\right)$ year load growth of both Ishashi $(3,263.27 \mathrm{~kW})$ and Ilogbo $(2,200.12 \mathrm{~kW})$ gave an average load demand of both Ishashi and Ilogbo communities as $1,305.31 \mathrm{~kW}$ and $880.05 \mathrm{~kW}$ respectively. With the use of equation (6) and power factor of 0.8 , the average energy demands of Ishashi and Ilogbo were converted to kVA value as $1631.63 \mathrm{kVA}$ and 1,100.06 $\mathrm{kVA}$ respectively. These values of load demand in $\mathrm{kVA}$ imply that four $500 \mathrm{kVA}$ and three $500 \mathrm{kVA}$ transformers would respectively serve Ishashi and Ilogbo communities. More so, special considerations were given to Ishashi community having proposed games village and market with Water Corporation. Therefore, two $300 \mathrm{kVA}$ transformers were considered sufficient for the market and proposed game centre because of the nature of equipment that might be involved. The proposed mini stadium can easily be supplied from the nearest $500 \mathrm{kVA}$ transformer substation since it is located in the core of Ishashi community. Furthermore, one $300 \mathrm{kVA}$ was considered sufficient for Ilogbo community with general hospital.

For the sizing of the feeder pillar, equation (8) and the transformer ratings were employed. The rated secondary current which is determinant of the feeder pillar rating for $500 \mathrm{kVA}$ and $300 \mathrm{kVA}$ transformer with 33 $\mathrm{kV}$ was calculated to be $695.60 \mathrm{~A}$ and $417.36 \mathrm{~A}$ respectively. Usually in practice feeder pillars are available in ratings of $200 \mathrm{~A}, 400 \mathrm{~A}$ and $800 \mathrm{~A}$ and based on the calculated rated secondary current of $500 \mathrm{kVA}$ and 300 $\mathrm{kVA}$ transformers, the appropriate feeder pillar for this work is $800 \mathrm{~A}$, 4-way distribution unit for both transformer types. 
For the conductor and cable selection, since the rated secondary current for $500 \mathrm{kVA}$ and $300 \mathrm{kVA}$ transformers was calculated to be $695.60 \mathrm{~A}$ and $417.36 \mathrm{~A}$ respectively, the size of the cables that connect the secondary of the two transformer types to the feeder pillar was selected as $500 \mathrm{~mm}^{2}$ and $300 \mathrm{~mm}^{2}$ for $500 \mathrm{kVA}$ and $300 \mathrm{kVA}$ transformers respectively. Also, for the cables that connect the feeder pillar to the low tension line (up-riser), $4 \times 185 \mathrm{~mm}^{2}$ insulated PVC sheathed 4 core-armoured cable was also selected since the current per functional unit of the feeder pillar for $500 \mathrm{kVA}$ transformer is $174 \mathrm{~A}$ and that for $300 \mathrm{kVA}$ transformer is 104.3 A. Also, since the rated primary current of the two transformer types was calculated as $8.75 \mathrm{~A}$ and $5.25 \mathrm{~A}$ respectively for $500 \mathrm{kVA}$ and $300 \mathrm{kVA}$ transformers using equation (8), $70 \mathrm{~mm}^{2}$ AAC (all aluminium conductor) was selected as the transmission/distribution conductor to reduce losses.

The number of high tension poles required by Ishashi and Ilogbo was calculated as 71 and 30 respectively using equation (11), inter-township connection length of Ishashi $(2.65 \mathrm{~km})$ and Ilogbo $(1.13 \mathrm{~km})$ and a condition that at every $400 \mathrm{~m}$, there must be a sectional pole (for strength of the line). The number of low tension poles required by Ishashi and Ilogbo was calculated as 122 and 135 respectively using equation (11) and township distribution connection length of Ishashi $(8.72 \mathrm{~km})$ and Ilogbo $(7.44 \mathrm{~km})$. Also, the conductor length of the high tension line for Ishashi and Ilogbo was calculated as $8,745 \mathrm{~m}$ and 3,729 $\mathrm{m}$ using equation (10) and wastage factor of 1.1. Similarly, the conductor length of the low tension for Ishashi and Ilogbo was calculated as $38,368 \mathrm{~m}$ and $24,552 \mathrm{~m}$ using equation (10) and wastage factor of 1.1. Ishashi required about 117 disc insulators, 174 pin insulators and 772 shackle insulators whereas Ilogbo required about 45 disc insulators, 75 pin insulators and 660 shackle insulators. The summary of the few of essential components required for the electrification of Ishashi and Ilogbo are presented in Tables 9 and 10 respectively.

Table 9: Estimated number of few of the substation's components for electrification of Ishashi Community

\begin{tabular}{|c|c|c|}
\hline $\mathbf{S} / \mathbf{N}$ & Material description and specification & Quantity \\
\hline 1 & $500 \mathrm{kVA}, 33 / 0.415 \mathrm{kV}$ Distribution Transformer & 4 \\
\hline 2 & $300 \mathrm{kVA}, 33 / 0.415 \mathrm{kV}$ Distribution Transformer & 2 \\
\hline 3 & 4-way feeder pillar & 6 \\
\hline 4 & $33 \mathrm{kV}$ Lightning Arrester & 18 \\
\hline 5 & $33 \mathrm{kV} \mathrm{J} \&$ P fuses & 18 \\
\hline 6 & Earthing of substation & 6 \\
\hline 7 & Plinth & 6 \\
\hline 8 & Fencing of Substation & 6 \\
\hline 9 & $500 \mathrm{~mm}^{2}$ single core PVC SWA/PVC cable (in metres) & 96 \\
\hline 10 & $300 \mathrm{~mm}^{2}$ single core PVC SWA/PVC cable (in metres) & 48 \\
\hline 11 & $35 \mathrm{~mm}^{2}$ single core XPLE cable (in metres) & 270 \\
\hline 12 & $4 \times 185 \mathrm{~mm}^{2} \mathrm{PVC} / \mathrm{SWA} / \mathrm{PVC}$ cable (up-riser) (in metres) & 270 \\
\hline 13 & 10.06 metres concrete poles (high tension poles) & 71 \\
\hline 14 & Pin insulators and spindle & 174 \\
\hline 15 & Socket, tongue, tension clamp, J-Hook & 117 \\
\hline 16 & Disc Insulator & 117 \\
\hline 17 & $70 \mathrm{~mm}^{2}$ Aluminum conductor (in metres) for high tension line & 8,745 \\
\hline 18 & 8.5 metres concrete poles (low tension poles) & 122 \\
\hline 19 & D-iron A complete set Comprises of D-iron, shackle insulator and spindle & 772 \\
\hline 20 & $70 \mathrm{~mm}^{2}$ Aluminum conductor (in metres) for low tension line & 38,368 \\
\hline
\end{tabular}

Table 10:Estimated number of few of the substation's components for electrification of Ilogbo Community

\begin{tabular}{|c|c|c|}
\hline $\mathbf{S} / \mathbf{N}$ & Material description and specification & Quantity \\
\hline 1 & $500 \mathrm{kVA}, 33 / 0.415 \mathrm{kV}$ Distribution Transformer & 3 \\
\hline 2 & $300 \mathrm{kVA}, 33 / 0.415 \mathrm{kV}$ Distribution Transformer & 1 \\
\hline 3 & 4-way feeder pillar & 4 \\
\hline 4 & $33 \mathrm{kV}$ Lightning Arrester & 12 \\
\hline 5 & $33 \mathrm{kV} \mathrm{J} \&$ P fuses & 12 \\
\hline 6 & Earthing of substation & 4 \\
\hline 7 & Plinth & 4 \\
\hline 8 & Fencing of Substation & 4 \\
\hline 9 & $500 \mathrm{~mm}^{2}$ single core PVC SWA/PVC cable (in metres) & 72 \\
\hline 10 & $300 \mathrm{~mm}^{2}$ single core PVC SWA/PVC cable (in metres) & 24 \\
\hline 11 & $35 \mathrm{~mm}^{2}$ single core XPLE cable (in metres) & 180 \\
\hline 12 & $4 \times 185 \mathrm{~mm}^{2} \mathrm{PVC} / \mathrm{SWA} / \mathrm{PVC}$ cable (up-riser) (in metres) & 180 \\
\hline 13 & 10.06 metres concrete poles (high tension poles) & 30 \\
\hline 14 & Pin insulators and spindle & 75 \\
\hline 15 & Socket, tongue, tension clamp, J-Hook & 45 \\
\hline 16 & Disc Insulator & 45 \\
\hline 17 & $70 \mathrm{~mm}^{2}$ Aluminum conductor (in metres) for high tension line & 3,729 \\
\hline 18 & 8.5 metres concrete poles (low tension poles) & 135 \\
\hline
\end{tabular}


The developed lectrical model design of Ishashi and Version Software and are presented in Figs. 1 and 2 respectively. The green, blue and cyan lines represent respectively the existing $33 \mathrm{kV}$ grid that passes through the two communities, proposed high tension and low tension lines. The transformer substations were also shown with overlapping circles symbols.

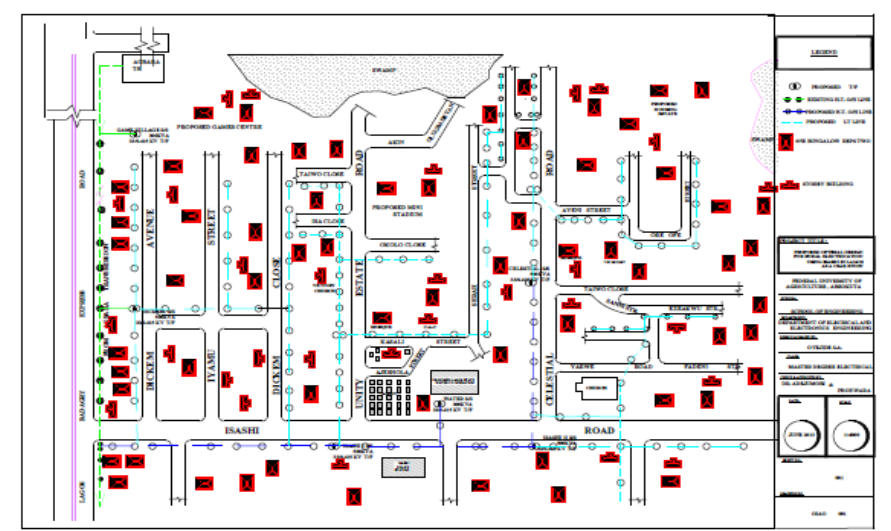

Figure 1: electrical design layout of Ishashi community

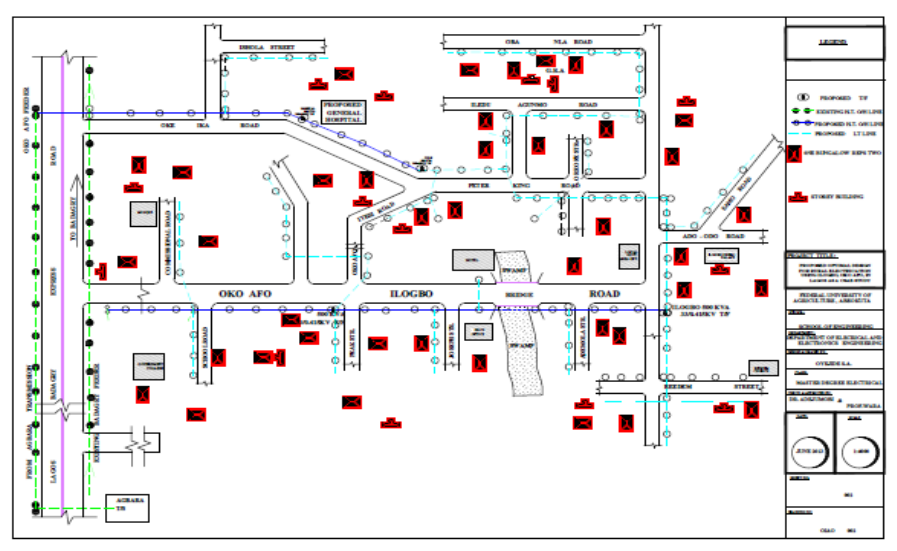

Figure 2: electrical design layout of Ilogbo community

\section{Conclusion}

In this work, a grid-based rural electrification designs had been developed using Ishashi and Ilogbo which are two rural communities located in Lagos State, South Western Nigeria as case studies. Although, the work revealed that Ishashi requires more components for its electrification than Ilogbo owing to difference in lengths of network connections and load demands, the two communities could easily be electrified using grid extension method taken into advantagethe fact that an existing functional grid ( $33 \mathrm{kV}$ line) passes through the two communities which will aid the reduction in technical challenges. One major limitation of the work presented here is that the effect of voltage drop on the placement of transformer substations was not put into consideration because the two communities are short lines and so the effect of voltage drop was neglected. However, further work is on-going to study the effect of voltage drop on the substation locations of both Ishashi and Ilogbo andalso to assess the possibilities of using offgrid-based technologies such as generator sets, renewable technologies including biomass, small hydropower scheme, solar photovoltaic and wind hybrid for electrifying Ishashi and Ilogbo and evaluate the cost implication of such electrification and compare with grid-based technology adopted in this work to determine the easier, better and economically more viable means to electrify the two communities. Finally, the electrical model designs developed in this work and information provided could be employed for the actualization of electrification of both Ishashi and Ilogbo communities. 


\section{References}

[1] Practicalaction, Technical brief on energy for rural communities. Retrieved October 1, 2012 from http://www.practicalaction.org

[2] I.A. Adejumobi, and O.I. Adebisi, Exploring small hydropower potentials for domestic and information communication technology infrastructural application in rural communities in Nigeria, Proc. of the $12^{\text {th }}$ Biennial International Conf. of Botswana Institution of Engineers, Gaborone, Botswana, 2011, 19-26.

[3] I.A. Adejumobi, and O.I. Adebisi, Equipment selection for a sustainable small hydro power scheme, Top Research Group Conf., Lome, Togo, 2011.

[4] I.A. Adejumobi, S.G. Oyagbinrin, F.G. Akinboro, and M.B. Olajide, Hybrid solar and wind power: an essential for information communication technology infrastructure and people in rural communities, IJRRAS, 9 (1), 2011, 130-138.

[5] A. Chaurey, M. Ranganathan, and P. Mohanty, Electricity access for geographical disadvantaged rural communities, Elsevier Journal of Energy Policy, 32, 2004, $1693-1705$.

[6] A.N. Zomers, Rural electrification, doctoral diss., University of Twente, The Netherlands, 2011.

[7] Power Holding Company of Nigeria (PHCN), Agbara Business Unit, Agbara, Ogun State, Nigeria, 2012.

[8] J.B. Gupta, A course in power system (New Delhi, India: S.K. Katari and Sons Publisher, 2011).

[9] D.P. Kothari and I.J. Nagrath, Power system engineering (New Delhi, India: Tata McGraw-Hill Publisher, 2008)

[10] Japan International Cooperation Agency (JICA), Manual and guidelines for micro-hydropower development in rural electrification, Department of Energy, Energy Utilization Management Bureau. Volume 1, 2009.

[11] G.D. Kamalapur and R.V. Udaykumar, Rural electrification in changing paradigm of power sector reforms in India, International Journal of Electrical and Computer Engineering, 2 (2), 2012, 147-154.

[12] A.S. Pabla,Electric power distribution (New Delhi, India: Tata McGraw-Hill Publisher, 2011). 